\title{
Longitudinal study of brucellosis in mice by immunoassay of lipopolysaccharide-related antigens in blood and urine
}

\author{
J. N. LIMET, A. BERBINSCHI, A. CLOECKAERT, C. L. CAMBIASO and P. L. MASSON
}

Unit of Experimental Medicine of the International Institute of Cellular and Molecular Pathology and Université Catholique de Louvain, 75, avenue Hippocrate, 1200 Brussels, Belgium

\begin{abstract}
Summary. Immunoassays based on latex agglutination or enzyme labelling (ELISA) were devised for the detection of lipopolysaccharide (LPS) of Brucella abortus, or its degradation products, in biological fluids of infected mice. The agglutination of latex was measured by counting of the remaining non-agglutinated particles in an automated immunoassay analyser. LPS was assayed by agglutination with antibodycoated latex and by competitive inhibition of agglutination of LPS-coated latex by anti-LPS antiserum. The inhibition system was more sensitive for the detection of degradation products of LPS. Correlation between ELISA and agglutination inhibition immunoassay was excellent $(r=0 \cdot 96)$. Degradation of LPS occurred during storage, particularly when the samples contained specific antibodies. It could be prevented by removing cells immediately after collecting blood samples and by heating or alkaline denaturation of plasma.

$\mathrm{CBA} / \mathrm{H}$ mice were infected with various doses $\left[65-\left(65 \times 10^{6}\right) \mathrm{cfu}\right]$ of B. abortus biovar 3 cells and the course of infection followed by immunoassay of LPS-related antigens in serum and urine, and by titration of specific antibodies and non-specific circulating immune complexes. The concentration of LPS degradation products, assayed by the agglutination inhibition assay, was related to the severity of the infection, which was assessed by viable counts of $B$. abortus in the spleen. A close correlation was observed between the values of antigenaemia, the number of $\mathrm{cfu}$ $(r=0.97)$, and the inoculum size $(r=0.99$ at day 28$)$.
\end{abstract}

\section{Introduction}

Brucellosis could be diagnosed earlier by detection of bacterial antigens in body fluids than by antibody titration or by culture. Assays of brucella antigens in vitro (Perera et al., 1983) and in bovine vaginal discharges (I-Ming-Chen et al., 1983) have been described but the detection of antigen in the blood of infected animals has not been reported previously.

Taking into account the rapid antigenic alteration of lipopolysaccharides (LPS) after contact with plasma or plasma fractions (Skarnes et al., 1958; Landy et al., 1959; Rudbach and Johnson, 1962), we constructed sensitive immunoassays to detect monovalent (haptenic) and polyvalent O-chain fragments of brucella LPS.

Here, we report the detection of brucella LPS

Received 12 Jan. 1987; revised version accepted 15 May 1987. fragments in the blood of mice infected with Brucella abortus, and the optimal conditions for blocking or reducing the alteration of bacterial antigens during processing and storage of samples. We also studied the course of brucella infection by measuring levels of antigenaemia, splenic viable counts, antibody responses and the levels of circulating immune complexes.

\section{Materials and methods}

\section{Reagents}

Glycine-buffered saline (GBS): $0.17 \mathrm{M} \mathrm{NaCl}, 0.1 \mathrm{M}$ glycine and $6.15 \mathrm{mM} \mathrm{NaN}_{3}$, adjusted to $p \mathrm{H} 9.2$ with $\mathrm{NaOH}$. GBS-EDTA : the same buffer containing $50 \mathrm{~mm}$ EDTA. GBS-EDTA-BSA: the same buffer containing bovine serum albumin (BSA, 98\% electrophoretically pure; Calbiochem-Behring corp., La Jolla, CA 92037, USA) $1 \mathrm{mg} / \mathrm{ml}$. 


\section{Bacteria}

B. abortus biovar 3 was a smooth field strain, freshly isolated at the National Institute for Veterinary Research (Brussels) from an infected cow. After growth for $48 \mathrm{~h}$ at $37^{\circ} \mathrm{C}$ in $\mathrm{CO}_{2} 5 \%$ in air, on Tryptic Soy Agar (Difco) supplemented with glycerol $1 \%$, bacteria were removed from plates and washed three times with isotonic saline. The final suspension was standardised turbidimetrically and viable counts determined for each experiment.

\section{Mice}

Male and female, 8-10-week old $\mathrm{CAB} / \mathrm{H}$ mice (Iffa Credo, Lyon, France) were used in all experiments. Mice were infected intraperitoneally or orally with live suspensions of B. abortus as indicated in the Results section. Groups of mice were killed at various times after inoculation. Plasma or serum samples were collected at various times and frozen at $-20^{\circ} \mathrm{C}$ until examined. For urine assays, mice were kept in metabolic cages and 24-h urine samples were collected each week.

\section{Brucella enumeration in spleens}

After thawing, spleens were minced with pointed forceps, and homogenised with a tight pestle in a Dounce tube. Serial 10-fold dilutions were seeded onto supplemented tryptic soy agar and colonies were counted after incubation for one week.

\section{Storage and treatments of samples}

For determining the optimal conditions for storage of samples, LPS was added to blood or plasma to a final concentration of $12.5 \mathrm{ng} / \mathrm{ml}$ and the samples were incubated in various conditions as indicated in the Results section. Each assay was preceded by alkaline denaturation of the plasma and, when necessary, by removal of the cells.

\section{Alkaline denaturation of samples}

One volume of serum, plasma or urine was mixed with 3 volumes of $0 \cdot 1 \mathrm{~N} \mathrm{NaOH}$ and incubated for $30 \mathrm{~min}$ at $70^{\circ} \mathrm{C}$. The mixture was then neutralised by adding one volume of $0.8 \mathrm{M}$ boric acid to give a final $p \mathrm{H}$ of 8.5-9.

\section{Brucella LPS and HPS}

LPS was extracted by the water-phenol procedure of Westphal and Jann (1965). The phenol phase was then precipitated by 3 volumes of cold methanol reagent $(99$ parts of methanol and 1 part of methanol saturated with sodium acetate) and treated with dimethylsulphoxide and $\mathrm{NaI}$ as described by Moreno et al. (1979). After extraction, LPS was dialysed exhaustively against water, and lyophilised. The polysaccharide hapten of brucella LPS (HPS) was prepared according to the method of Mosimann (1949) and was a gift of G. Dubray from
Institut National de la Recherche Agronomique (Nouzilly, France).

\section{Anti-LPS antiserum}

New-Zealand White rabbits were immunised over 6 months by the fortnightly administration by intra-dermal injection of killed $B$. abortus biovar $3\left(10^{8} \mathrm{cfu}\right)$. In immunoblotting experiments with both smooth and rough Brucella LPS, immune serum samples from these rabbits were found to be specific for smooth LPS. The IgG fraction and $F(a b)_{2}{ }_{2}$ fragments were prepared as previously described (Limet et al., 1982).

\section{Immunoassays by enzyme labelling}

Ninety-six well microtitration plates (Greiner-Labortechnik, Stutgart, FRG) were incubated overnight at $37^{\circ} \mathrm{C}$ with anti-brucella IgG $4 \mu \mathrm{g} / \mathrm{ml}$ in GBS $20 \%$, (a blocking step was not necessary). Coated plates were stored either at $4^{\circ} \mathrm{C}$ or washed, dried and sealed in plastic bags containing a desiccant capsule. In this condition they may be stored at $4^{\circ} \mathrm{C}$ for at least 6 months. For the LPS assays, coated plates were incubated with $50 \mu \mathrm{l}$ of sample for $2.5 \mathrm{~h}$ at room temperature, washed five times with $0.15 \mathrm{M} \mathrm{NaCl}$ containing Tween $200.1 \%$, and reincubated for $1.5 \mathrm{~h}$ at room temperature with horseradish peroxidase-labelled $\mathrm{F}(\mathrm{ab})^{\prime}{ }_{2}$ fragments of the same IgG preparation used to coat the plates. Labelled antibody, coupled to horseradish peroxidase by the method of Nakane and Kawaoi (1974), was diluted 1 in 2000 in GBS-EDTA supplemented with Tween $200.1 \%$ and fetal calf serum $2 \%$. A standard curve was prepared by serial dilution of LPS $10 \mathrm{ng} / \mathrm{ml}$ in normal bovine serum. LPS standards were pretreated as for test samples before assay.

\section{Immunoassays by latex agglutination}

Immunoassays of antigen, antibody titrations and assays of immune complexes were performed in an automated immunoassay analyser (IMPACT; Acade Diagnostic Systems, Brussels, Belgium), in which the degree of latex agglutination is determined by counting the remaining non-agglutinated particles (Masson et al., 1981). The analyser dilutes, mixes, incubates with agitation in a thermostat-controlled water bath and passes the reaction mixture to an optical particle counter by a proportioning pump. The number of non-agglutinated particles is recorded and the concentration of the analyte is interpolated from a dose-response curve for standards by means of a Hewlett Packard 85 computer, which also controls all the operations.

LPS assays were based either on the agglutination of antibody-coated latex by LPS (direct agglutination) or on the inhibition by LPS of agglutination of LPS-coated latex by anti-LPS antibodies (agglutination inhibition).

Latex coating. For the direct agglutination test, latex was coated with the $\mathrm{F}(\mathrm{ab})^{\prime}{ }_{2}$ fragments of rabbit anti-LPS IgG as previously described (Limet et al., 1982). For the 
agglutination inhibition system, latex was coated with LPS (Limet et al., 1985) by incubation of $50 \mu \mathrm{l}$ of a $10 \%$ w/v latex suspension (K109 Rhône-Poulenc Courbevoie, France) with $100 \mu \mathrm{g}$ of LPS in $0.4 \mathrm{ml}$ of GBS $20 \%$. The mixture was sonicated (Branson, Danbury, CTO6810) and after $10 \mathrm{~min}$, latex was stabilised by adding $200 \mu \mathrm{g}$ of human serum albumin (Behringwerke, Marburg/Lahn, FRG) in GBS $20 \%$. After incubation for $20 \mathrm{~min}$ at room temperature, LPS-coated latex suspensions were resuspended in $1 \mathrm{ml}$ of sodium dodecyl sulphate $1 \% \mathrm{w} / \mathrm{v}$ and sonicated again. After incubation for a further hour at $37^{\circ} \mathrm{C}$, the latex was washed twice with $1 \mathrm{ml}$ of GBS $20 \%$, once with $1 \mathrm{ml}$ of GBS-EDTA-BSA and then resuspended in $1 \mathrm{ml}$ of the latter. LPS-coated latex was stored in small volumes at $-20^{\circ} \mathrm{C}$ for up to 2 years without loss of agglutinability. When thawed, latex was sonicated for $15 \mathrm{~s}$ and diluted 60-fold in GBS-EDTA-BSA supplemented with rheumatoid factor serum $0 \cdot 1 \% \mathrm{v} / \mathrm{v}$. Rheumatoid factor serum was from a patient with rheumatoid arthritis and was used to enhance the weak agglutinating activity of IgG antibodies. The latex suspension containing the rheumatoid factor could also be stored lyophilised for more than 9 months without loss of activity.

Direct agglutination. After alkaline denaturation, $30 \mu \mathrm{l}$ of sample were mixed with $30 \mu \mathrm{l}$ of antibody-coated latex $0.01 \% \mathrm{w} / \mathrm{v}$. The mixture was vortex-mixed at $37^{\circ} \mathrm{C}$ for $40 \mathrm{~min}$, diluted twenty times with GBS, and the particles were counted. In this system the number of nonagglutinated particles is inversely proportional to the LPS concentration.

Agglutination inhibition. After alkaline denaturation, samples $(30 \mu \mathrm{l})$ were incubated for $30 \mathrm{~min}$ with $30 \mu \mathrm{l}$ of antiserum diluted 1 in 25000 in GBS-EDTA-BSA and then incubated for a further $12 \mathrm{~min}$ with the latex suspension $0.01 \% \mathrm{w} / \mathrm{v}$ containing rheumatoid factor $0.1 \%$ $\mathrm{v} / \mathrm{v}$. The number of free particles in this assay is proportional to the LPS concentration.
Anti-brucella antibody titration. IgM and IgG class antibrucella antibodies were detected by their agglutinating activity for LPS-coated latex particles. For IgG antibody titration, IgM antibodies were inactivated by treatment with dithiothreitol and the agglutination by IgG antibodies was enhanced by rheumatoid factor (Limet et al., 1985).

Immune complex assay. Immune complexes were detected by their inhibition of agglutination of IgGcoated latex by mouse serum agglutinating factor (Cambiaso et al., 1979).

\section{Precipitation of immune complexes by polyethylene glycol (PEG)}

Serum samples $(400 \mu \mathrm{l})$ were incubated for $16 \mathrm{~h}$ at $4^{\circ} \mathrm{C}$ with $400 \mu \mathrm{l}$ of $10 \mathrm{mM}$ phosphate buffer $(p \mathrm{H} \mathrm{7.5)} \mathrm{con-}$ taining $50 \mathrm{mM}$ EDTA and $200 \mu \mathrm{l}$ of PEG 6000120 $\mathrm{g} / \mathrm{L}$. The resultant precipitate was centrifuged at $15000 \mathrm{~g}$ for $20 \mathrm{~min}$, washed with PEG $25 \mathrm{~g} / \mathrm{L}$ and dissolved in $300 \mu \mathrm{l}$ of $0.1 \mathrm{~N} \mathrm{NaOH}$. After a further incubation of $30 \mathrm{~min}$ at $70^{\circ} \mathrm{C}$, the solution was neutralised with $100 \mu \mathrm{l}$ of $0.8 \mathrm{M}$ boric acid, and the antigen was assayed by agglutination inhibition as described above.

\section{Results}

\section{Calibration of immunoassays}

The threshold of detection of LPS added to alkaline-denatured normal mouse plasma was about $0.1 \mathrm{ng} / \mathrm{ml}$ in ELISA, direct agglutination and agglutination inhibition assays (fig. 1). All three assays detected antigenaemia in mice infected with B. abortus $\left(7 \cdot 5 \times 10^{5} \mathrm{cfu}\right) 15$ days previously (fig. 2$)$. However, the direct agglutination assay could only

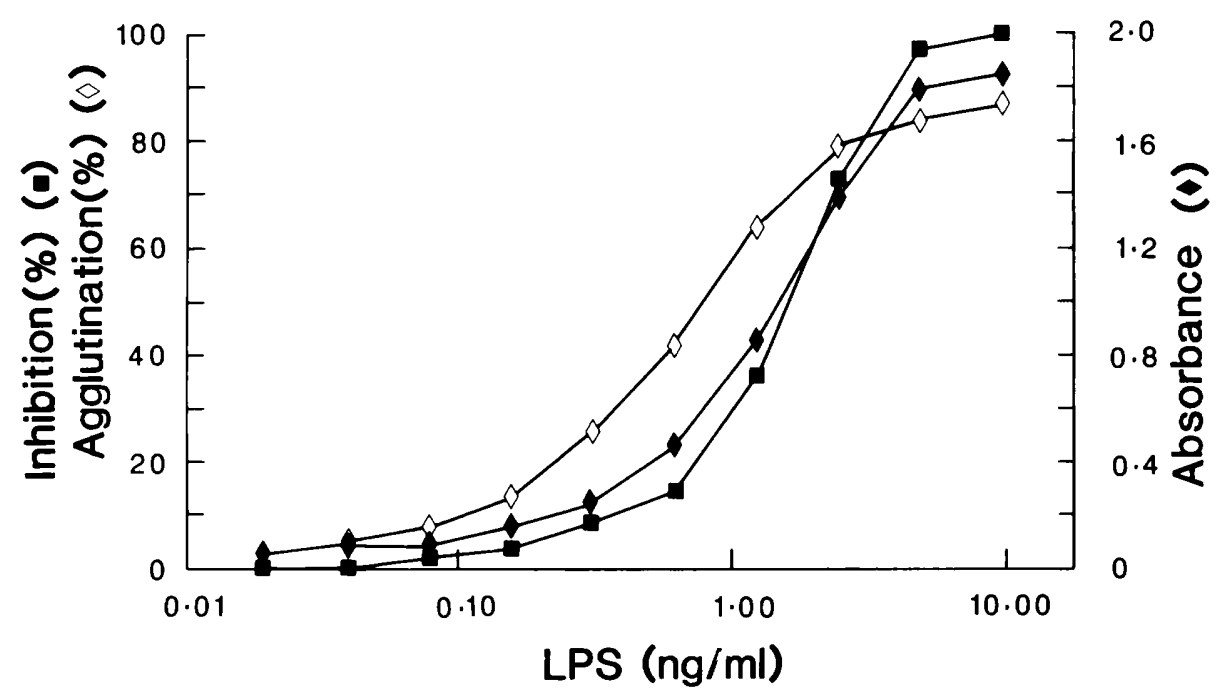

Fig. 1. Calibration curves for the immunoassay of brucella LPS added to alkaline-denatured normal mouse plasma by direct latex agglutination $(\diamond)$, agglutination inhibition $(\square)$, and ELISA $(\diamond)$. 
just detect brucella antigen at the first dilution and was similarly poor at detecting HPS added to alkaline-denatured mouse serum (fig. 2). For all three assays, the dilution curves of the samples from infected mice were clearly different from those given by LPS, but similar to those given by HPS, the acid-hydrolysed LPS. Results of the assays of circulating antigens in 107 infected mice showed a linear correlation of $r=0.96$ between agglutination inhibition and ELISA (fig. 3). However, in sera from mice infected with less than $65 \times 10^{3} \mathrm{cfu}$ brucella antigens were detected by the agglutination inhibition assay only. Coefficients of variation, calculated from same-day results on replicate samples, were less than $4 \%$ for the three tests (table I).

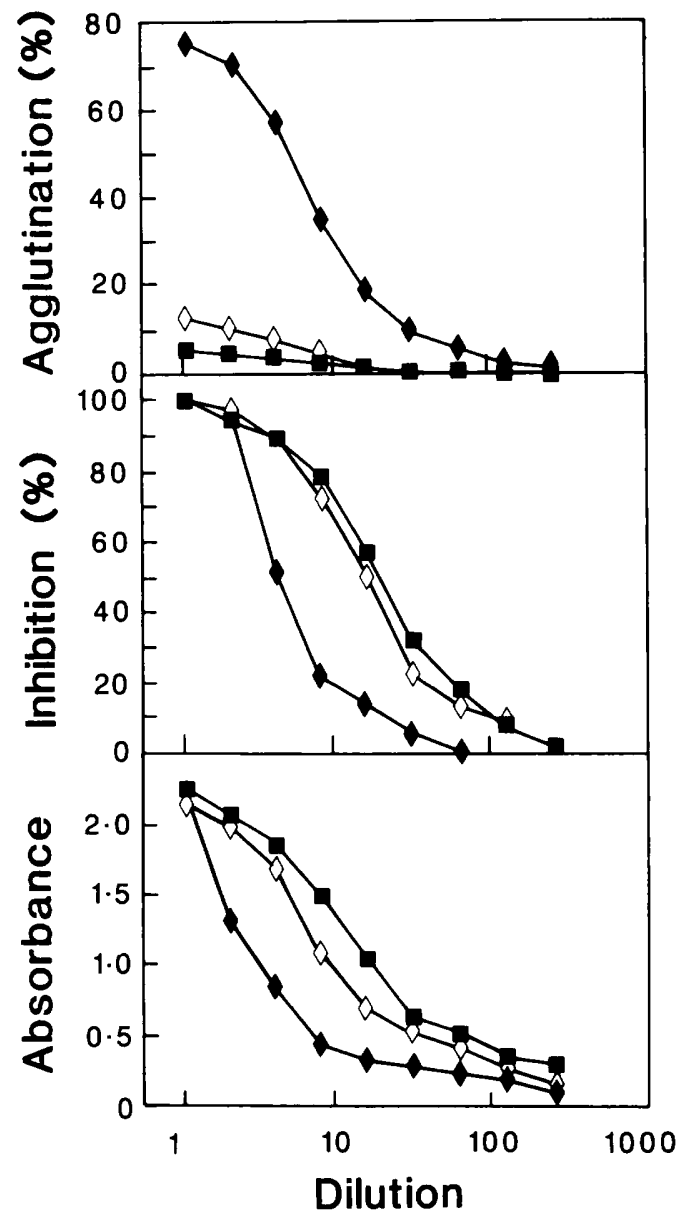

Fig. 2. Dilution curves of brucella LPS ( $\bullet)$, brucella HPS $(\diamond)$ and circulating antigen ( $\boldsymbol{D}$ ) in the direct latex agglutination assay (top), agglutination inhibition assay (middle) and ELISA (bottom). All dilutions were made in alkaline-denatured normal mouse serum. The first dilutions correspond to LPS $5 \mathrm{ng} / \mathrm{ml}$, HPS $25 \mathrm{ng} / \mathrm{ml}$ and to a 1 in 10 dilution of the plasma from infected mice.

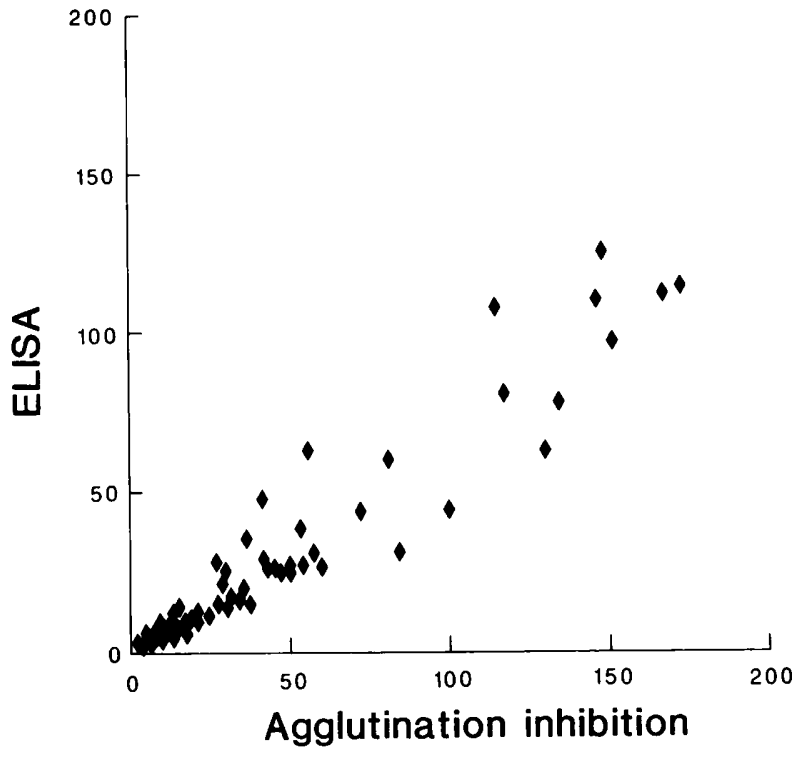

Fig. 3. Correlation between the results of the immunoassay of circulating brucella antigens by agglutination inhibition and by ELISA in samples from infected mice $(n=107 ; r=0.96$, $\mathrm{p}<0.001 ; \mathrm{y}=0.692 \times-1.638)$. Results are expressed in equivalents of HPS.

Table I. Intra-assay coefficients of variation (C.V.) for the latex agglutination tests and ELISA

\begin{tabular}{c|ccc}
\hline & \multicolumn{3}{|c}{ Intra-assay C.V. $(\%)$ for } \\
\cline { 2 - 4 } $\begin{array}{c}\text { LPS concentration } \\
(\mathrm{ng} / \mathrm{ml})\end{array}$ & $\begin{array}{c}\text { direct } \\
\text { agglutination* }\end{array}$ & $\begin{array}{c}\text { agglutination } \\
\text { inhibition* }\end{array}$ & ELISA $\dagger$ \\
\hline 5 & 2.86 & 3.2 & 1.39 \\
1 & 0.92 & 2.4 & 3.68 \\
0.5 & 0.8 & 2.4 & 3.32 \\
\hline
\end{tabular}

* C.V. calculated for results of 20 replicate samples on the same day.

$\dagger$ C.V. calculated for results of 6 replicate samples on the same day.

\section{Degradation of LPS in samples}

Serum samples with detectable LPS gave lower values in direct agglutination assays after storage for several weeks at $-20^{\circ} \mathrm{C}$. This may have been the result of masking of the antigen by antibody or, more likely, LPS antigen degradation. To explore the best conditions for avoiding the degradation of LPS after blood collection, we added LPS to plasma and whole blood from mice, and incubated the samples in various conditions with or without pretreatment. Plasma was used instead of serum 
because we had already observed a better recovery of the antigens when blood was heparinised. LPS was then assayed by direct agglutination and agglutination inhibition. Loss of detectable LPS was particularly evident in the direct agglutination assay (table II). LPS degradation was faster in stored whole blood than in plasma, but addition of azide to whole blood slowed down the process. Despite alkaline-denaturation of samples, the presence of anti-LPS antibodies in the sample markedly reduced LPS detection. Heat-treating plasma $\left(60^{\circ} \mathrm{C}\right.$ for $30 \mathrm{~min}$ ) before storage or storage at $p \mathrm{H} 11$ partially reversed this effect (table III). Storage at low temperature also protected LPS; the analytical recovery by direct agglutination in plasma was only $30 \%$ after incubation for $17 \mathrm{~h}$ at room temperature but $75 \%$ when the samples were kept on ice for a similar time (data not shown).

Table II. Assay of brucella LPS by latex agglutination after incubation in mouse plasma or whole blood at $37^{\circ} \mathrm{C}$

\begin{tabular}{|c|c|c|}
\hline \multirow[b]{2}{*}{$\begin{array}{l}\text { Sample and storage } \\
\text { conditions }\end{array}$} & \multicolumn{2}{|c|}{ Analytical recovery ( $\%$ ) of LPS by } \\
\hline & $\begin{array}{c}\text { direct } \\
\text { agglutination }\end{array}$ & $\begin{array}{l}\text { agglutination } \\
\text { inhibition }\end{array}$ \\
\hline $\begin{array}{l}\text { Plasma (heparin } 15 \mathrm{IU} / \\
\mathrm{ml} \text { ) }\end{array}$ & 88 & 100 \\
\hline $\begin{array}{l}\text { Plasma containing anti- } \\
\text { LPS antibodies }\end{array}$ & 40 & 100 \\
\hline Whole blood & 30 & 60 \\
\hline $\begin{array}{l}\text { Whole blood containing } \\
\text { anti-LPS antibodies }\end{array}$ & 0 & 15 \\
\hline $\begin{array}{l}\text { Whole blood containing } \\
\text { anti-LPS antibodies + } \\
\text { azide ( } 30 \mathrm{~mm})\end{array}$ & 32 & 100 \\
\hline
\end{tabular}

Table III. Assay of brucella LPS by direct latex agglutination in mouse plasma or whole blood after storage at room temperature

\begin{tabular}{c|cccc}
\hline & \multicolumn{4}{c}{$\begin{array}{c}\text { Analytical recovery (\%) of LPS } \\
\text { after storage for }\end{array}$} \\
\cline { 2 - 5 } \multicolumn{1}{c|}{ Sample } & $1 \mathrm{~h}$ & $4 \mathrm{~h}$ & $20 \mathrm{~h}$ & $84 \mathrm{~h}$ \\
\hline $\begin{array}{c}\text { Plasma (heparin } 15 \mathrm{IU} / \mathrm{ml}) \\
\begin{array}{c}\text { Plasma heated at } 60^{\circ} \mathrm{C} \text { for } \\
30 \mathrm{~min}\end{array}\end{array}$ & 85.7 & 68.6 & $45 \cdot 1$ & 11.4 \\
$\begin{array}{c}\text { Plasma at } p \mathrm{H} 11(\mathrm{glycine} \\
\text { buffer) }\end{array}$ & 100 & 68.6 & 74.3 & 71.4 \\
\begin{tabular}{c} 
Whole blood $+30 \mathrm{~mm}$ azide \\
\hline
\end{tabular} & - & - & 104.7 & 92 \\
\hline
\end{tabular}

- not done

\section{Longitudinal study of brucella infection in mice}

The severity of the infection caused by intraperitoneal injection of $7.5 \times 10^{5} \mathrm{cfu}$ of $B$. abortus was estimated by viable counts in the spleen. Viable counts reached a maximum approximately one week after inoculation and then decreased gradually (fig. 4). Organisms could still be recovered on day 112. Two peaks of antigenaemia were observed (fig. 4) - 1 day after inoculation and about 2 weeks later. At peak 1, the direct agglutination and agglutination inhibition assays gave similar results but peak 2 was much more evident with the inhibition procedure, which indicates that at this time most circulating antigens were degradation products of small molecular size. Antigens were also found in the urine where their concentration measured by the inhibition assay varied in parallel with their concentration in serum (fig. 5). The antigens present in the urine failed to agglutinate antibody-coated latex, again suggesting that they were small fragments unbound to antibody.

Antibodies to brucella were assayed by agglutination of LPS-coated latex. IgM class antibodies, appeared at day 4 (data not shown) and IgG class antibodies at day 7 (fig. 6). The agglutinating activity of the anti-LPS antibodies suggested that they were at least partially in a free form.

After injection, the level of circulating immune complexes decreased until day 10 , then increased in parallel with the antibody levels (fig. 6). We expected to recover significant amounts of LPS or HPS in the immune complexes that were precipitated with PEG. However, for a serum sample $(400 \mu \mathrm{l})$ collected at day 40 which contained a total of $3.2 \mathrm{ng}$ of LPS equivalents only $0.15 \mathrm{ng}(5 \%)$ was recovered in the precipitate.

\section{Antigenaemia and severity of infection}

To test whether antigenaemia was a reliable index of the severity of the infection, we inoculated mice with increasing doses of $B$. abortus from 65 to $65 \times 10^{6} \mathrm{cfu}$. At day 7 antigenaemia was proportional to the infecting dose (fig. 7, upper panel), but did not correlate with splenic viable counts $(r=0 \cdot 74$, fig. 8 upper panel). At day 28 , antigenaemia was again proportional to infecting dose (fig. 7, lower panel) and also correlated with splenic viable counts $(r=0.97)$ (fig. 8, lower panel).

Peak levels of antigenaemia occurred later with smaller inocula $\left(6.5 \times 10^{3}\right.$ or less) (fig. 9). When mice were given $10^{8} \mathrm{cfu}$ by mouth, a maximum of $10^{3} \mathrm{cfu} /$ spleen were found and circulating antigens could not be detected (data not shown). 


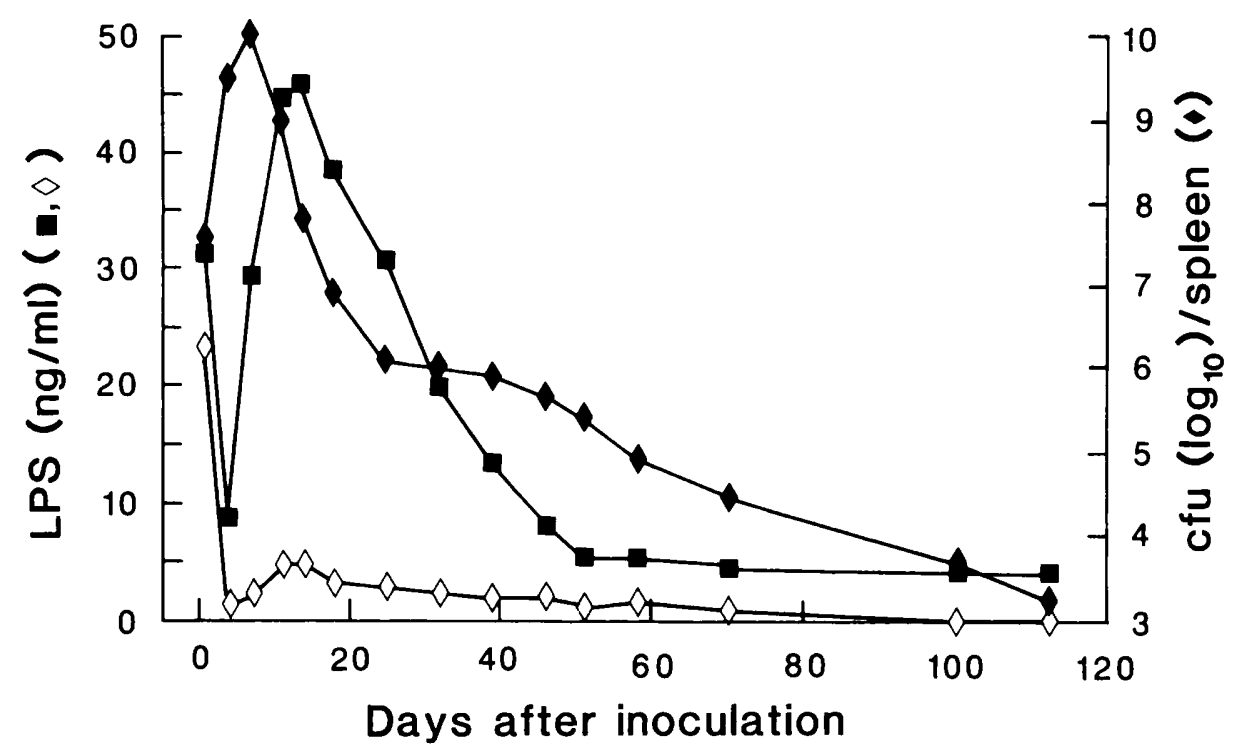

Fig. 4. Viable counts of brucella in the spleen $(\diamond)$ and circulating antigen assayed by direct agglutination $(\diamond)$ or by agglutination inhibition $(\square)$ in mice given intraperitoneal injections of B. abortus $\left(7.5 \times 10^{5} \mathrm{cfu}\right)$. Groups of four mice were killed on the days indicated.

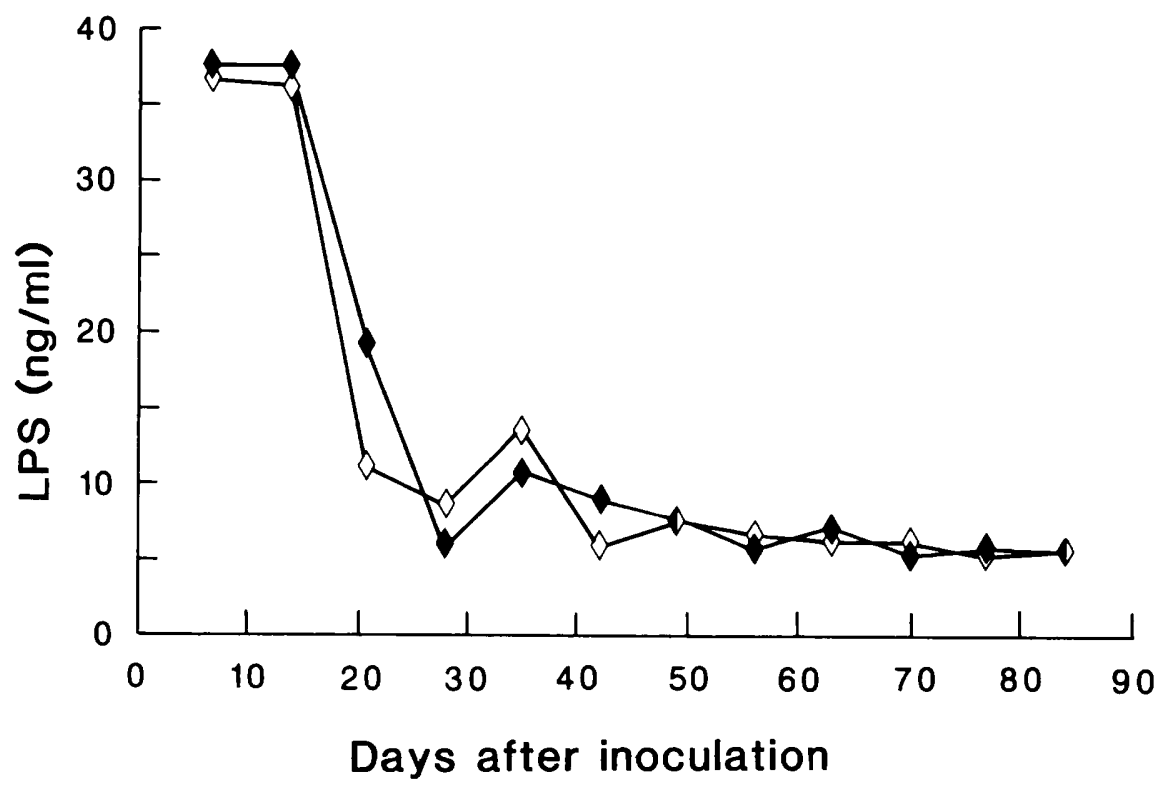

Fig. 5. Brucella antigens were assayed by agglutination inhibition in the serum $(\diamond)$ and urine $(\diamond)$ of mice given intraperitoneal injections of $B$. abortus $\left(2 \times 10^{6} \mathrm{cfu}\right)$.

\section{Discussion}

We have shown that brucellosis may be diagnosed in mice by detection of bacterial antigens in plasma or urine. Of the three methods developed, the agglutination inhibition system was the most efficient. In contrast to direct agglutination, the agglutination inhibition assay and ELISA were only weakly affected by the hydrolysis of LPS. In mice infected with very low doses of brucellae $(65 \times$ $\left.10^{3} \mathrm{cfu}\right)$ circulating antigens were detected by agglutination inhibition but not by ELISA. Latex agglutination assayed in the IMPACT instrument also has the advantages of automation and speed, 


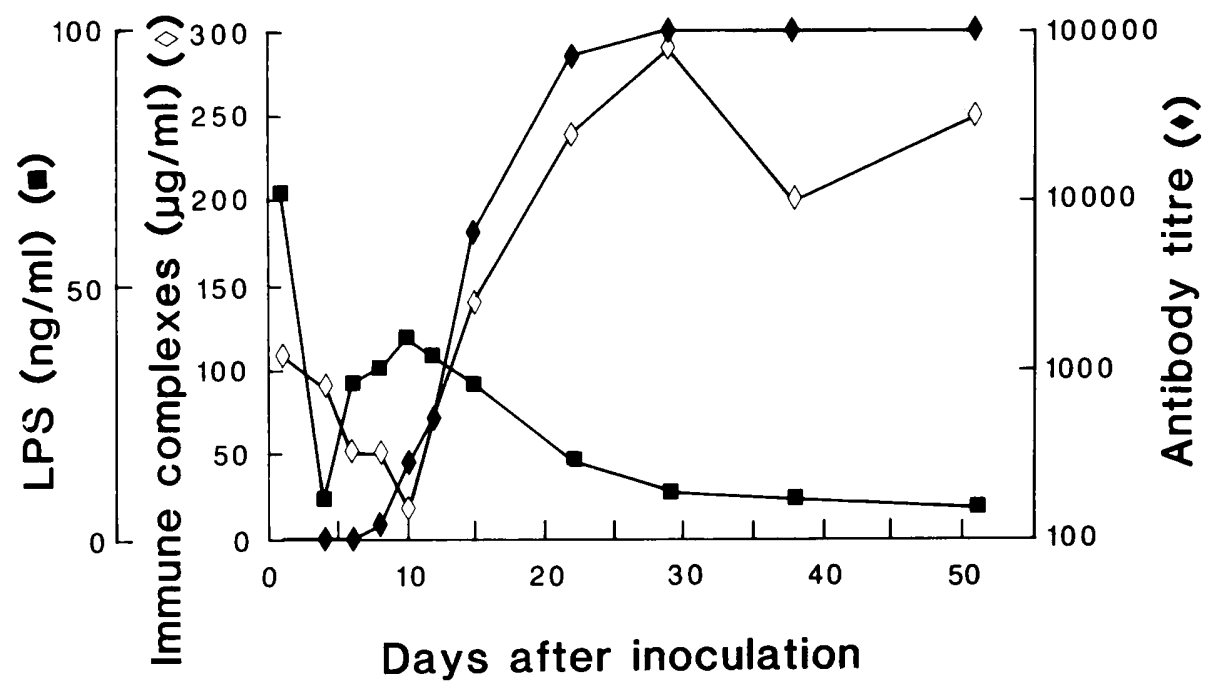

Fig. 6. Levels of immune complexes $(\diamond)$, brucella antigens $(\square)$ assayed by agglutination inhibition, and IgG antibodies $(\diamond)$ in serum of mice given intraperitoneal injections of $B$. abortus $\left(2 \times 10^{5} \mathrm{cfu}\right)$.

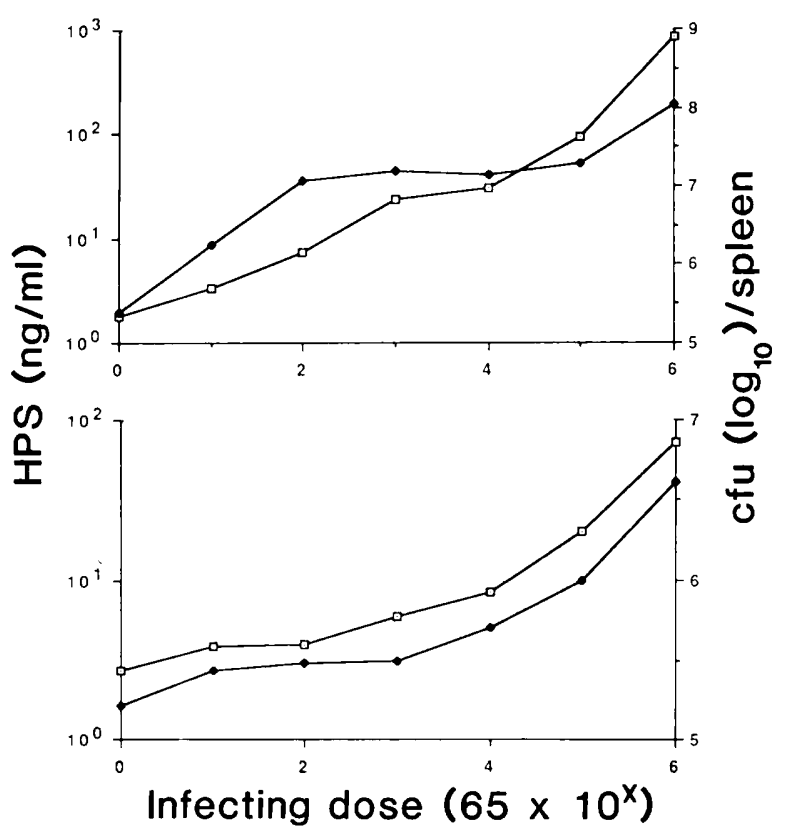

Fig. 7. Correlation between infecting dose, level of antigenaemia $(\square)$ and viable counts ( $\bullet), 7$ days (upper panel) and 28 days (lower panel) after intraperitoneal injection with $B$. abortus with $65-\left[65 \times 10^{6}\right] \mathrm{cfu}$. Antigenaemia was assayed by agglutination inhibition and results expressed as equivalents of LPS.

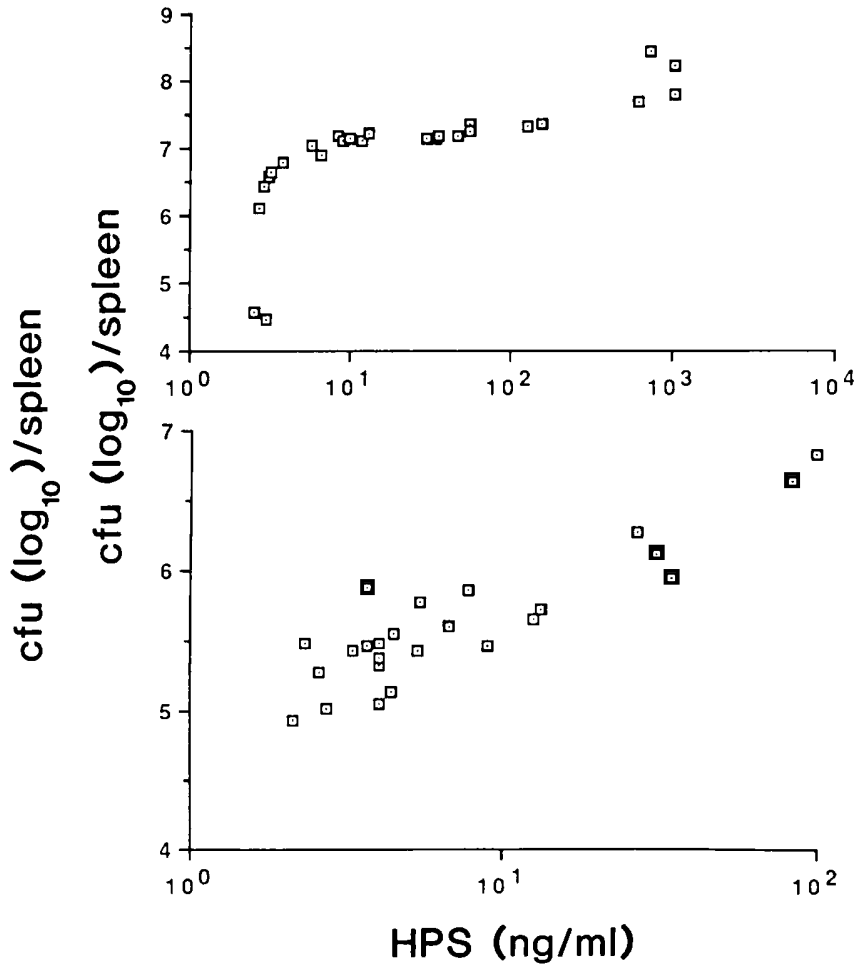

Fig. 8. Correlation between viable counts and the level of antigenaemia in mice 7 days (upper panel) and 28 days (lower panel) after intraperitoneal injection of $B$. abortus $\left(65-\left[65 \times 10^{6}\right]\right.$ $\mathrm{cfu})$.

Antigenaemia was assayed by agglutination inhibition and the results were expressed as equivalents of HPS. 


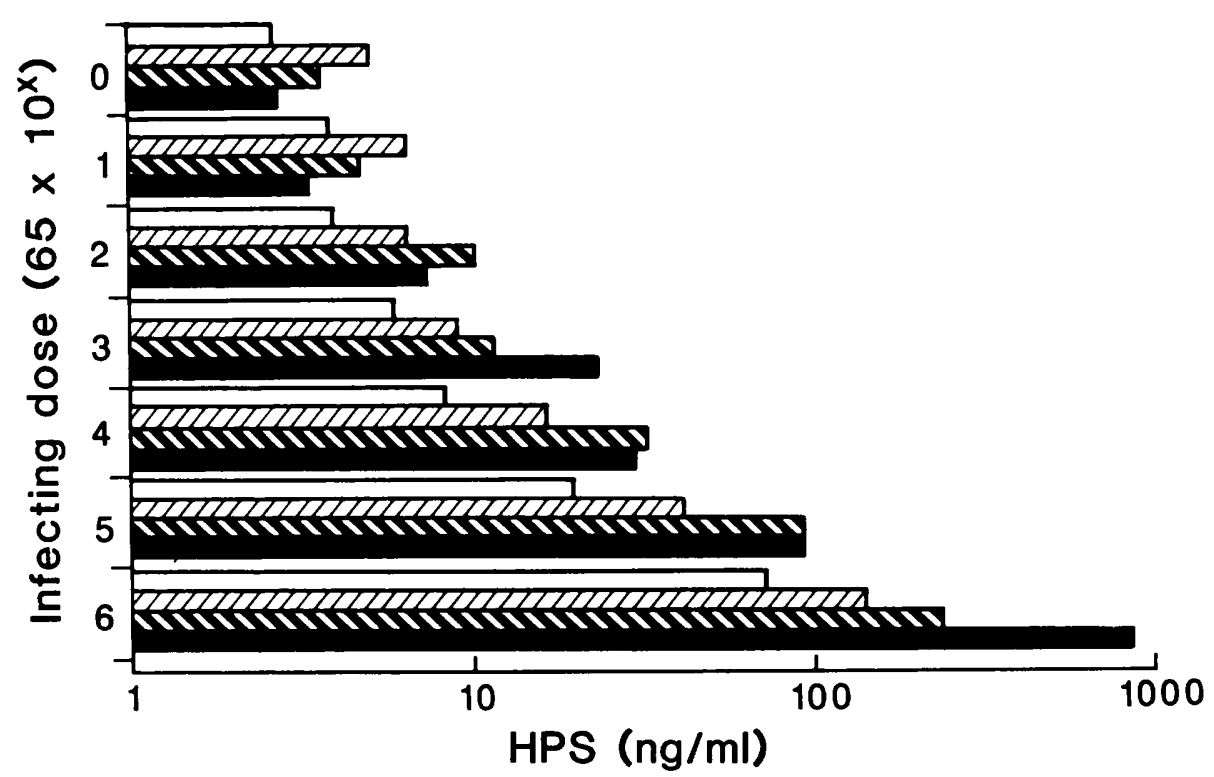

Fig. 9. Evolution of the antigenaemia in relation to infecting dose. Mice were infected as described in fig. 8. Plasma samples were collected weekly for one month and assayed by the agglutination inhibition assay: $\square$ first week, $\square$ second week, $\square$ third week and $\square$ fourth week.

results being available within $75 \mathrm{~min}$ instead of $5 \mathrm{~h}$ with ELISA.

Alkaline denaturation of samples is essential to avoid non-specific agglutination and non-specific inhibition by interfering factors and to release antigen trapped in immune complexes. Ideally such treatment should be applied just after blood collection and removal of cells because the recovery of brucella LPS was affected by the presence of blood cells and plasma proteins, particularly in the presence of anti-LPS antibody. Azide slowed down the process in whole blood probably by interfering with endocytosis.

LPS from other bacteria has also been shown to be unstable. Typhoid endotoxin, after incubation in serum, failed to elicit antibodies when injected into rabbits (Skarnes, et al., 1958; Landy et al., 1959). Splitting of LPS during incubation with Cohn's fraction IV of serum was suggested by immunodiffusion patterns (Rudbach and Johnson, 1962). Radiolabelled LPS of Salmonella abortus equi, when injected intravenously, is partially excreted in urine as dialysable fragments (Kleine $e t$ al., 1985). Uptake of typhoid LPS by human neutrophil leukocytes and its degradation in the granules has also been described (Hall and Munford, 1983).

Infection caused by intraperitoneal inoculation of $B$. abortus into mice was severe; viable counts $>10^{5} \mathrm{cfu} /$ spleen were found after injection of only
$65 \mathrm{cfu}$. When infection was less severe and viable counts remained at only $10^{3} \mathrm{cfu} / \mathrm{spleen}$, as obtained by oral infection, LPS antigens were not detected. The oral route is probably the more frequent route of infection in cattle. However, in pilot experiments we have detected brucella antigens in a proportion of spontaneously infected cattle (unpublished data).

By quantifying the antigenaemia it was possible to estimate the severity of the infection in mice. This was shown by the close correlation between the level of antigenaemia, the number of cfu/spleen and the infecting dose. In human brucellosis, the evaluation of the severity of the infection might be useful in monitoring antibiotic therapy.

The simultaneous detection of free antigen and free antibodies as well as the low recovery of antigen in PEG precipitated immune complexes was surprising. At day 40 , antibodies would be expected to be in excess and the serum agglutinating activity in the presence of LPS-coated latex is consistant with this. It is less clear how part of the antigen could be free of antibodies and detectable in the urine. Possibly, in contrast to the rabbit antibodies used in the immunoassay, antibodies produced by the infected mice are directed mainly against intact LPS and react only weakly with LPS fragments, which could then cross the renal filter.

It is generally accepted that normal individuals have circulating immune complexes, presumably involving autoantibodies and anti-idiotypic anti- 
bodies (Pope et al., 1975; Morgan et al., 1979). After injection of brucella cells the level of immune complexes decreased for a few days and then rose in parallel with the titre of specific antibodies. The initial fall may have been the result of endocytosis of immune complexes by macrophages which have been activated by the infection. The induction of circulating immune complexes by infection with $B$. suis in mice has also been reported (Cannat et al., 1983).

The simultaneous presence of LPS derived antigens and anti-LPS antibodies in the serum suggests that most of the circulating antigens should be recovered as immune complexes. However, only a minor proportion of the antigens was recovered in the PEG precipitate. The agglutination inhibition test gave higher values of antigenaemia than the direct agglutination test, which indicates that the circulating antigens may have been fragments

\section{REFERENCES}

Cambiaso C L, Sindic C, Masson P L 1979 Particle counting immunoassay (PACIA) III. Automated determination of circulating immune complexes by inhibition of an agglutinating factor of mouse serum. Journal of Immunological Methods 28: 13-23.

Cannat A, Escande A, Peraldi F, Serre A 1983 Induction of autoantibodies and circulating immune complexes in mice after injection of Brucella fraction "PI" or inoculation with live Brucella suis. Annales d'Immunologie (Paris) 134 C: 4353.

Hall C L, Munford R S 1983 Enzymatic deacylation of the lipid A moiety of Salmonella typhimurium lipopolysaccharides by human neutrophils. Proceedings of the National Academy of Science of the USA 80: 6671-6675.

Chen I M, Thoen CO, Pietz D E, Harrington R 1984 Application of an enzyme-linked immunosorbent assay for detection of Brucella antigens in vaginal discharges of cows. American Journal of Veterinary Research 45 : 32-34.

Kleine B, Freudenberg M A, Galanos C 1985 Excretion of radioactivity in faeces and urine of rats injected with ${ }^{3} \mathrm{H}$, ${ }^{14} \mathrm{C}$-lipopolysaccharide. British Journal of Experimental Pathology 66: 303-308.

Landy M, Trapani R J, Shear M J 1959 Inactivation of endotoxin by a humoral component. IV. Alteration in the immunological properties of typhoid endotoxin. Journal of Experimental Medicine 110: 731-750.

Limet J N, Collet-Cassart D, Magnusson C G, Sauvrage P, Cambiaso C L, Masson P L 1982 Particle counting immunoassay (PACIA) of ferritin. Journal of Clinical Chemistry and Clinical Biochemistry 20 : 141-146.

Limet J N, Berbinschi A C, De Cleen D, Van Aert A, Dekeyser P, Masson P L 1985 Automated particle-counting immunoassay of anti-Brucella antibodies a comparative study with ELISA, SAT, CFT, RBP and AGT. In: Verger J M, Plommet $\mathrm{M}$ (eds) Brucella melitensis. Martinus Nijhoff Publishers for the Commission of the European Communities, pp 155-166. of LPS. If these fragments were mono-or oligovalent, insufficient antibody molecules might have bound to them to produce immune complexes precipitable by $2.5 \%$ PEG. However if that were so, they could also be too small to react with antimouse antibody used for their detection. We believe that our assay detected only a small fraction of the specific immune complexes, i.e., those that reacted with the anti-mouse antibody and were PEG precipitable, which presumably would be immune complexes containing only intact LPS or large LPS fragments and complexes made of self-associated IgG which occur in normal individuals and increase after certain immune stimuli.

This work was supported by Grants Nos. 3441 A, 3960 A and 4486 A from the Institut pour la Recherche Scientifique dans l'Industrie et l'Agriculture. We thank Dr J. Dekeyser for helpful discussions. The excellent technical assistance of A. de Boeck, J-L. Guarin and J. Van Broeck was greatly appreciated.

Masson P L, Cambiaso C L, Collet-Cassart D, Magnusson C G M, Richards C B, Sindic C J M 1981 Particle counting Immunoassay (PACIA). In: Langone $\mathrm{J} J$ (ed), Methods in enzymology. Academic Press Inc., New York, USA, 74: 106-139.

Moreno E, Pitt M W, Jones L M, Schurig G G, Bermam D T 1979 Purification and characterization of smooth and rough lipopolysaccharides from Brucella abortus. Journal of Bacteriology 138: 361-369.

Morgan A C, Roger J R, Rossen D, Twomey J J 1979 Naturally occurring circulating immune complexes: normal human serum contains idiotype-anti-idiotype complexes dissociable by certain IgG antiglobulins. Journal of Immunology 122: $1672-1680$.

Mosimann W 1949 Allergene aus Brucella abortus Bang. Schweizerische Zeitschrift für Pathologie und Bakteriologie 12: 362-379.

Nakane P K, Kawaoi A 1974 Peroxidase-labeled antibody: a new method of conjugation. The Journal of Histochemistry and Cytochemistry 22: 1084-1091.

Perera V Y, Creasy M T, Winter A J 1983 Nylon bead enzymelinked immunosorbent assay for detection of sub-picogram quantities of Brucella antigens. Journal of Clinical Microbiology 18: 601-608.

Pope R M, Teller D C, Mannik M 1975 The molecular basis of self-association of IgG-Rheumatoid factors. Journal of Immunology 115: 365-373.

Rudbach J A, Johnson A G 1962 Changes in serologic reactivity of endotoxin induced by fraction IV $_{1}$ (Cohn) of normal human serum. Proceedings of the Society for Experimental Medicine and Biology 111: 651-655.

Skarnes R C, Rosen F S, Shear M J, Landy M 1958 Inactivation of endotoxin by a humoral component. II. Interaction of endotoxin with serum and plasma. Journal of Experimental Medicine 108: 685-699.

Westphal O, Jann K 1965 Bacterial lipopolysaccharides. Extraction with phenol-water and further applications of the procedure. In: Whistler R L (ed) Methods in carbohydrate chemistry, vol V. Academic Press Inc., New York, pp 83-91. 